\title{
Study on Evaluation of Agricultural Irrigation Zoning and Optimal Utilization of Water Resources in Yantai City
}

\author{
Hong Hou ${ }^{l}$, Youqian Qiao ${ }^{2}$, Xiangran $\mathrm{Li}^{3 *}$ \\ ${ }^{1}$ School of Economics and Business administration, Yantai university, Yantai 264000, China; \\ ${ }^{2}$ Bureau of Housing and Urban-rural development, Zoucheng city, Jining 272000, China; \\ ${ }^{3}$ School of Civil Engineering, Yantai university, Yantai 264000, China
}

\begin{abstract}
Agricultural water is the largest water user in Yantai City, and its water consumption accounts for more than $2 / 3$ of the total water consumption in Yantai City. The potential for agricultural water saving is huge, but the overall level of agricultural water efficiency in Yantai City is not very high, and the waste of water resources is serious. Efficient agricultural water use in Yantai is a key issue for achieving efficient and sustainable use of water resources in Yantai. Different regions in the study area have different social and economic developments, different industrial structures, and different natural climates, and their investments in agricultural water conservancy facilities are also different. In order to better study the agricultural efficient water use model in Yantai City. This article will divide the agricultural irrigation subarea according to the actual situation of Yantai.
\end{abstract}

\section{Current situation of agricultural water in Yantai city}

Yantai is a typical coastal water-scarce city. The situation of agricultural water use is very severe. Seasonal precipitation and uneven regional distribution. When the water use gap is large, agricultural water use is often squeezed out first. It can be seen from the table that even in the year of abundant water, the actual agricultural water consumption in Yantai City only accounts for $42 \%$ of the planned water consumption; the extremely dry year such as 2000 only accounts for $27 \%$ of the planned water consumption.

Since 2009, Yantai has accelerated the development of agricultural water-saving, developing water-saving irrigation of $340,000 \mathrm{mu}$ accumulatively, saving 46 million cubic meters of water annually, and constantly improving its agricultural water-saving capacity.As of 2016, Yantai City's agricultural water-saving irrigation reached 4.85 million mu, accounting for $90 \%$ of the total irrigation area. Agricultural water consumption continued to grow negatively, effectively alleviating the city's water shortage. However, the form of agricultural water use is still grim, the phenomenon of waste still exists, and the efficient use of water in agriculture needs to be strengthened.
Table 1. Data table of actual agricultural water use of reservoir management units

\begin{tabular}{|c|c|c|c|c|c|}
\hline \multirow[t]{2}{*}{ Project } & \multirow{2}{*}{$\begin{array}{l}\text { Designed } \\
\text { agricultural } \\
\text { water } \\
\text { consumption } \\
(10,000 \mathrm{~m}) 3\end{array}$} & \multicolumn{2}{|c|}{$\begin{array}{c}\text { Actual } \\
\text { agricultural } \\
\text { water } \\
\text { consumption } \\
(10,000 \mathrm{~m}) 3\end{array}$} & \multicolumn{2}{|c|}{$\begin{array}{c}\text { Actual } \\
\text { proportion to } \\
\text { plan }\end{array}$} \\
\hline & & $\begin{array}{c}\text { In } \\
2012,\end{array}$ & $\begin{array}{c}\text { In } \\
2016,\end{array}$ & $\begin{array}{c}\text { In } \\
2012,\end{array}$ & $\begin{array}{c}\text { In } \\
2016 \text {, }\end{array}$ \\
\hline $\begin{array}{l}\text { Menlou } \\
\text { reservoir }\end{array}$ & 1000 & 0 & 20 & 0 & 20 \\
\hline $\begin{array}{l}\text { Muyu } \\
\text { reservoir }\end{array}$ & 800 & 300 & 500 & 37.5 & 62.5 \\
\hline $\begin{array}{l}\text { Taoyuan } \\
\text { reservoir }\end{array}$ & 360 & 50 & 100 & 14 & 28 \\
\hline $\begin{array}{l}\text { Anli } \\
\text { reservoir }\end{array}$ & 320 & 20 & 80 & 6.25 & 25 \\
\hline $\begin{array}{l}\text { Longmen } \\
\text { reservoir }\end{array}$ & 200 & 50 & 100 & 25 & 50 \\
\hline $\begin{array}{l}\text { Washan } \\
\text { reservoir }\end{array}$ & 280 & 10 & 120 & 4 & 43 \\
\hline $\begin{array}{l}\text { Lidian } \\
\text { reservoir }\end{array}$ & 300 & 50 & 100 & 17 & 33 \\
\hline A total of & 3660 & 1000 & 1530 & 27 & 42 \\
\hline
\end{tabular}

\section{Agricultural irrigation zoning and evaluation in Yantai city}

\subsection{Agricultural irrigation zoning of Yantai city}

Because the regional natural conditions, social development and residents' life style, different water 
resources distribution, the factors influencing the principal component analysis (PCA), will be a variety of weighting index screening indicators, again using the system clustering method, find out the index of similar areas, as a study area.1

In combination with the natural hydrological conditions, the current situation of social and economic development and residents' living standards in Yantai city, this paper adopts five index modules, including topographical features, climate characteristics, economic level, crop planting structure and agricultural water irrigation district is more, so this paper first USES efficiency, including 11 indexes, to construct a complete index system, as shown in figure 1.In this paper, DPS data processing system is used for principal component analysis which simplifies the original complex multiindicator system to a few representative and important comprehensive indicators. Then, DPS system is continued to be used for cluster analysis of the selected indicators, and a pedigree map is drawn, as shown in Figure 2.

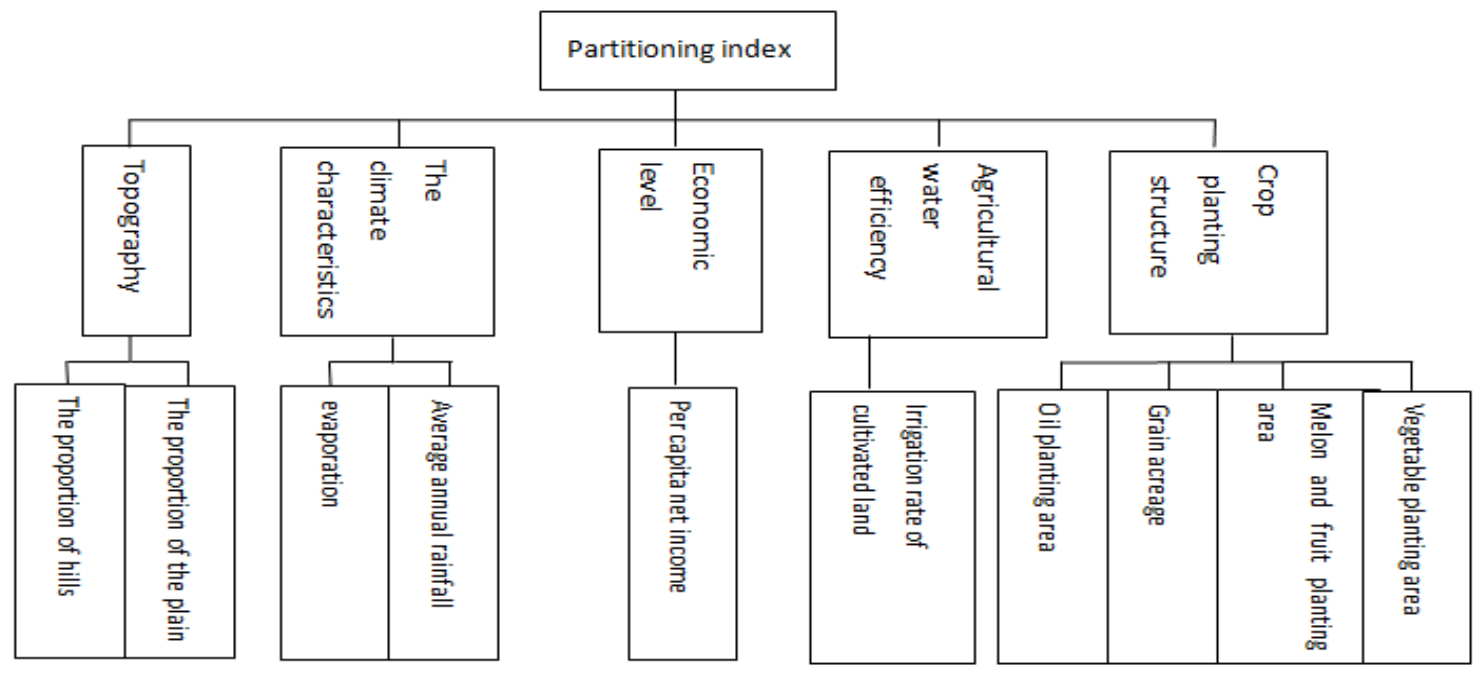

Fig 1. Index system of irrigated agriculture zone

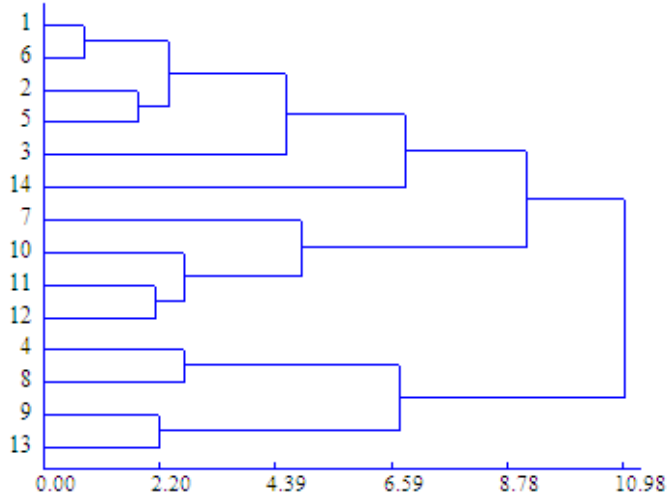

Fig 2. Cluster pedigree diagram

As can be seen from figure 2, when the threshold value is between 4.39 and 6.59 , the difference in the sum of squares of dispersion between the same partition indexes is not large, but the difference in the sum of squares of dispersion between different partition indexes is large. Thus the classification at $4.39<<6.59$ is the result of the irrigated agriculture subdivision of Yantai city.According to the results obtained by the method of dispersion sum of squares, the irrigated agriculture in Yantai city was divided into five districts (see figure 3). The basic partition units included for each partition are shown in Table 2.
Table 2. Irrigation zones

\begin{tabular}{cc}
\hline Partitin & Territorial \\
\hline I & Zhifu district, Laishan district, High-tech zone, \\
& Development zone, Fushan district \\
II & Longkou city, Laizhou city, Penglai city, Zhaoyuan city \\
III & Mouping district, Qixia city \\
IV & Laiyang city, Haiyang city \\
V & Changdao county \\
\hline
\end{tabular}

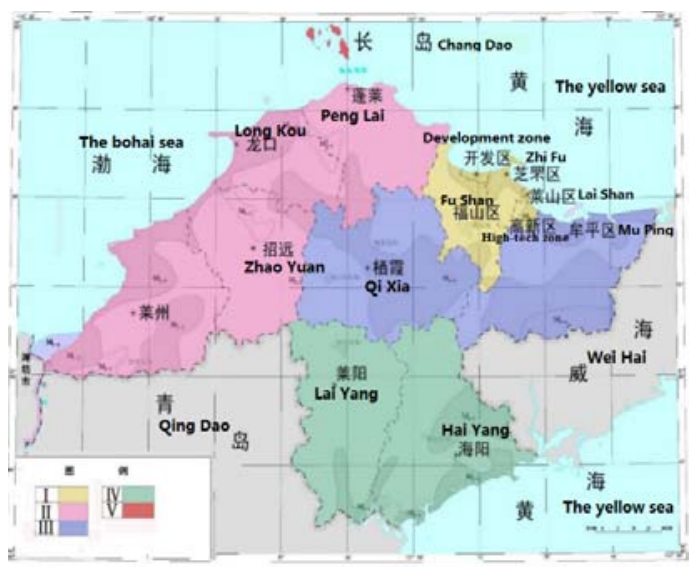

Fig 3.Schematic diageam of agricultural irrigation zoing in Yantai city 


\subsection{Characteristics and evaluation agricultural irrigation zones in Yantai city}

I area: Temperate monsoon climate, the average annual rainfall is $698.3 \mathrm{~mm}$. The spatial and temporal distribution of precipitation in the region is extremely uneven, often appear even years or even dry years. The terrain is complex, with rolling hills and valleys. This research area belongs to the urban area of Yantai city, which is mainly dominated by industry and commerce and residents' life, with a small proportion of agricultural production. Among them, peanut, melon and fruit are the main agricultural crops, and peanut is a drought-tolerant crop. Therefore, agricultural water-saving in this area is mainly targeted at orchards.

II area: Temperate monsoon region continental climate. There is plenty of precipitation in the area, but it is not evenly distributed between the year and the year. It is a major grain-producing area in Yantai city. The grain crop output accounts for $47 \%$ of the total output of Yantai city, mainly winter wheat, $31 \%$ of the total output of vegetables and fruits, and mainly grapes.Moreover, the water conservancy facilities are relatively perfect, and the effective irrigation area is close to $100 \%$.

III area: Continental climate is temperate monsoon type, precipitation change of time and space, and for many years, the average annual rainfall of $729 \mathrm{~mm}$, region distribution, decreasing from south to north, hill area accounted for $92.2 \%$ of total area, is an important vegetable melon and fruit production areas of Yantai.The construction of water conservancy facilities is relatively backward, the water conveyance channels are aging, and the water resource waste is serious. The proportion of advanced water conservancy facilities such as microirrigation, pipe irrigation and sprinkling irrigation is small, and the coefficient of water resource utilization is low.

IV area: Belongs to continental monsoon type subhumid climate, annual average precipitation $686 \mathrm{~mm}$. The terrain is high in the north and low in the south, with hills and hills accounting for $67.4 \%$ of the total area.Yantai city is a vegetable base, food crops large farmers.IV area in recent years, vegetable production in about half of Yantai production, food production accounted for Yantai more than $30 \%$ of the total grain output.The overall proportion of high-efficient watersaving agricultural irrigation area is small. The construction of water-saving agricultural irrigation has just started, the irrigation channels are aging seriously, and the water-saving construction is messy and not systematic enough.

$\mathrm{V}$ area: Is a warm temperate continental monsoon climate, years of average rainfall of $565 \mathrm{~mm}$.The administrative area only includes changdao county, which is mainly farmed by Marine products and has only 78 hectares for food crops. Therefore, the agricultural water-saving in this area is mainly intensive farming without wasting water resour.

\section{Analysis of efficient water use model and optimal utilization of water}

\section{resources in different irrigation areas in Yantai city}

Based on the results of agricultural irrigation zoning in Yantai city, according to the actual situation of each zone, advanced engineering technology, agronomy technology and management technology are applied to study the efficient water use model of agricultural irrigation in each zone.

\subsection{Agricultural irrigation area water model research}

More hills in the region, also belong to the semi-arid region, so the use of terraced soil moisture storage and moisture retention model; Secondly, melon and fruit like wetting and are afraid of standing water, so it is advisable to adopt the model of precise and efficient orchard irrigation [].3I area, therefore, the terrace water keep moisture and orchard irrigation mix efficient water use patterns.Terrace soil storage and soil moisture conservation, the slope is built as a terrace, in order to achieve the effect of rainfall interception, water storage and soil moisture conservation. The orchards are irrigated with precision and efficient water use model, which adopts drip irrigation, micro-spraying engineering, automatic management, and precise irrigation according to the growing environment of crops.

\subsection{Agricultural irrigation area water model research}

The agricultural water use in the region is mainly aimed at the winter wheat and grape crops to study the watersaving irrigation model.The planting method of winter wheat is furrow irrigation, and surface furrow irrigation, that is, small furrow irrigation mode of low-pressure pipeline, can be adopted.The irrigation quota for small furrows generally does not exceed $675 \mathrm{~m} / \mathrm{hm}$, which greatly improves the utilization rate of water resources. The efficient irrigation system is shown in Table 3.32The water-saving and efficient irrigation of grape drip irrigation means that the method of drip irrigation is applied in combination with the water-saving and efficient irrigation system of grape (see Table 4), which generally saves water by $30-50 \%$ compared with surface irrigation and $15-25 \%$ compared with sprinkler irrigation.

Table 3. Water-saving and efficient winter wheat irrigation system under surface furrow irrigation conditions

\begin{tabular}{ccccc}
\hline $\begin{array}{c}\text { Irrigation } \\
\text { period }\end{array}$ & $\begin{array}{c}\text { The } \\
\text { winter } \\
\text { water }\end{array}$ & $\begin{array}{c}\text { Filling } \\
\text { water }\end{array}$ & $\begin{array}{c}\text { Earing } \\
\text { water }\end{array}$ & $\begin{array}{c}\text { The whole } \\
\text { growth } \\
\text { period }\end{array}$ \\
\hline $\begin{array}{c}\text { Irrigation } \\
\text { amount } \\
(\mathrm{m} / \mathrm{hm}) 32\end{array}$ & 675 & 675 & 675 & 2025 \\
\hline
\end{tabular}


Table 4. Water-saving and efficient grape irrigation system under drip irrigation

\begin{tabular}{|c|c|c|c|c|c|}
\hline $\begin{array}{l}\text { Irrigation } \\
\text { period }\end{array}$ & $\begin{array}{l}\text { SAP } \\
\text { flow } \\
\text { period } \\
\text { Mid- } \\
\text { march } \\
\text { to } \\
\text { early } \\
\text { April }\end{array}$ & $\begin{array}{c}\text { New } \\
\text { growth } \\
\text { period } \\
\text { Middle } \\
\text { April } \\
\text { to } \\
\text { early } \\
\text { may } \\
\end{array}$ & 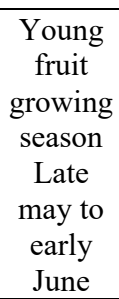 & $\begin{array}{c}\text { Maturity } \\
\text { of } \\
\text { branches } \\
\text { and } \\
\text { tendrils } \\
\text { October to } \\
\text { November }\end{array}$ & $\begin{array}{c}\text { The } \\
\text { whole } \\
\text { growth } \\
\text { period }\end{array}$ \\
\hline $\begin{array}{l}\text { Irrigation } \\
\text { amount } \\
(\mathrm{m} / \mathrm{hm}) 32\end{array}$ & 300 & 300 & 300 & 300 & 1200 \\
\hline
\end{tabular}

\subsection{Agricultural irrigation area water model research}

III area is an important vegetable melon and fruit production areas of Yantai, and water conservancy facilities construction relative lag, water use coefficient is low.Combined with the actual III area, put forward the reasonable mode of agricultural efficient water use (see figure 3).

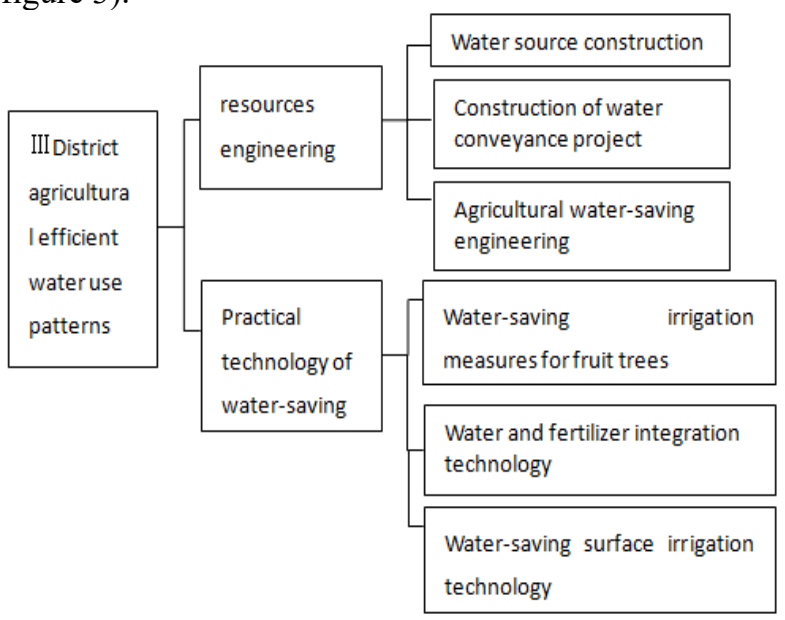

Fig 4. III district agricultural efficient water use patterns

\subsubsection{Construction of water sources}

Build reservoirs, DAMS and sluice gates and underground water retaining walls at suitable locations to increase water supply; Coastal counties and urban areas to carry out the construction of flood dyke, improve the ability to prevent storm surge; We will make overall plans for water conveyance projects through channels, build a number of new anti-seepage channels, upgrade and renovate aging channels, and reduce leakage and evaporation.We will vigorously develop water-saving projects in agriculture, build new irrigation facilities such as pipeline irrigation,

sprinkler irrigation, and micro-irrigation, and make irrigation in grain fields, orchards, greenhouses, microsprinkler drip irrigation, and farmland irrigation more scientific

\subsubsection{Practical technology of water-saving irrigation}

First, fruit tree water-saving irrigation includes strengthening orchard coverage, reasonable shaping and pruning, and timely water-saving irrigation.Orchard coverage to maintain soil moisture, saving water;Reasonable pruning can reduce leaf transpiration, improve photosynthetic efficiency and promote root growth.Timely water-saving irrigation to ensure the normal growth of fruit trees need water. Second, water and fertilizer integration technology. Through the lowpressure pipeline system and the irrigator on the final pipeline, the water containing soluble fertilizer can be delivered directly to the soil surface or soil layer near the root of the crop uniformly and accurately. Third, watersaving surface irrigation technology.It includes leveling the land, designing reasonable size of furrow and furrow and technical parameters of irrigation, improving the way of wetting surface irrigatio improving the way of water discharge, developing intermittent irrigation, vigorously developing water conservation and moisture film irrigation and so on.

\subsection{Agricultural irrigation area water model research}

Research IV district agricultural efficient water use pattern, first of all, upgrade aging water conservancy facilities, constructing water-saving irrigation project, including small and medium-sized irrigation and water saving reconstruction project and small water projects, complete engineering system layout.Secondly, the introduction of appropriate advanced irrigation techniques, namely, adjust measures to local conditions of the fed, sprinkler irrigation and microspray irrigation technology, cooperate with the implementation of agriculture, water conservancy, management, technical measures, such as establishing different mode of watersaving engineering technology, after years of practice, has formed for haiyang city engineering technology of water-saving irrigation for different types of regional development pattern.Finally, according to the terrain features, formation of small and medium-sized irrigation channel gravity irrigation and dig a canal for irrigation gravity irrigation, since the pressure pipe irrigation system, fixed pump $++\mathrm{rf}$ frequency conversion controller card + PVC - M + glass fiber reinforced plastic pipe outlet engineering irrigation irrigation mode, at the same time, with reference to the construction, the soil moisture monitoring system for pressure and flow of the above irrigation mode for real-time monitoring, precision measurement, according to the water supply, water price reform, ensure the long-term operation of the project.

\subsection{Agricultural irrigation area water model research}

$\mathrm{V}$ agricultural irrigation area in the administrative areas including changdao county, only 56 square kilometers land area, its agriculture mainly farming, there are only 
78 hectares of crops, wheat and corn are accounted for $50 \%, 39$ hectares, vegetables and fruits planting area is zero.Agricultural water-saving measures in changdao county mainly adopt water-saving irrigation technology, reduce flood irrigation, and promote sprinkling irrigation anddrip irrigation.We will upgrade and renovate backward water conveyance channels, phase out earth canals, strengthen the construction of impervious channels, and reduce evaporation and leakage of water resources. According to the favorable terrain, reasonable scale of tangba and reservoirs should be built to realize the effective storage of surface runof.

\section{Conclusions and Suggestions}

Yantai is a coastal city lacking water. With the continuous development of social economy and increasing population, the demand for water resources is increasing and the contradiction between supply and demand is intensifying.However, the phenomenon of flood irrigation still exists in the agricultural water consumption of Yantai city, which is the largest user of agricultural water. The low efficiency of agricultural water consumption leads to the serious waste of water resources, which restricts the rapid development of the social economy of Yantai city.Therefore, adopting reasonable measures to realize the efficient use of water for agriculture in Yantai city is an important way to ease the contradiction between the supply and demand of water resources in Yantai city and promote the sustainable development of social economy in Yantai city.

In this paper, the natural environment, social and economic development status, residents' living standards and agricultural development status of the area were taken into consideration, and the index system of irrigated agricultural zones was established. Then, the principal component analysis method and DPS system were used to draw a cluster genealogical chart. According to the genealogical chart, the research area could be divided into five different agricultural irrigation zones. I zone Zhifu, Laishan district, including Hightech zone, development zone, Fushan district; II area includingLongkou city, Laizhou city, Penglai city, Zhaoyuan;III area including Lai Yang city, Haiyang city; IV area including Muping county, qixia city; $\mathrm{V}$ area including Changdao county, and evaluate each partition for agricultural irrigation district.

On the basis of the evaluation results of irrigation zoning, according to the characteristics of each irrigation zoning, we made overall planning and adopted measures according to local conditions, combined with advanced engineering technology, agronomy technology and biotechnology, introduced advanced management theory, and developed a more effective and reasonable efficient water use model.

Agricultural efficient water use is an important link to realize efficient utilization of water resources, and Yantai city's agricultural water use is the largest user of water in Yantai city. Therefore, under the current situation of increasing demand for water resources in
Yantai city, increasingly prominent contradiction between supply and demand, and continuous occurrence of geological environment problems, the realization of efficient agricultural water use in Yantai city is an important measure to realize efficient utilization of water resources in Yantai city, the residents' living and working in peace and contentment, and the sustainable development of social economy.

\section{References}

1. Yuan Zhifa, Zhou Jingyao. Multivariate statistical analysis [M]. Beijing: Science Press, (2002)

2. $\mathrm{Xu} \mathrm{Yi,} \mathrm{Wang} \mathrm{Zhenlong,} \mathrm{Xu} \mathrm{Deqian.} \mathrm{Research} \mathrm{on}$ water-saving irrigation zoning in Anhui [J]. Rural Water Conservancy and Hydropower in China, (09): 44-47 ( 2013)

3. Qiao Yougan. Research on Environmental Effects and High-efficient Water Use Model of Water Resources Development and Utilization in Yantai City [D]. Yantai: Yantai University, (2014)

4. Wang Wei, Feng Yongjun, Li Qiguang, Wang Xin. Analysis of the development situation of agricultural irrigation in Shandong Province and the regional water-saving model $[\mathrm{J}]$. China Rural Water and Hydropower, (12):1-4+8(2012)

5. Challenging Issues over Sustainable Water Management in Coastal Area from China[J]. COASTAL EDUCATION \&amp; RESEARCH FOUNDATION, INC. [CERF],2018.

6. Wang Ailing, Chuan Limin. Open source and throttling of agricultural water use abroad and its inspiration to China[J].World Agriculture 2018(08):11-15.

7. Wei Mei, Liu Fusheng, Zhao Jinghui, Liu Dongliang, Liu Bo, Qiao Tianling. Study on watersaving irrigation zoning in Shandong Province based on agricultural standardization[J].Journal of Shandong Agricultural University (Natural Science Edition),2016,47(04):560-564.

8. Wang Xiqin, Wu Ruoran, Li Zhaojie, Yang Yonghui. Zoning and development countermeasures of agricultural water safety in my country[J]. Chinese Journal of Eco-Agriculture, 2016, 24(10): 1428-1434.

9. Wu Meng.Study on the division of agricultural water-saving management based on the relationship between water and energy in farmland irrigation system-Taking Shanghai as an example[J].Journal of Irrigation and Drainage,2018,37(02):116-122+128

10. Tong Jinping, Ma Jianfeng, Wang Huimin, Qin Teng, Liu Gaofeng.Water use efficiency and technological progress in agriculture: an empirical study based on China's agricultural panel data[J].Resource Science,2014,36(09):1765-1772. 